\title{
Between preferences: marriage and mobility among Danish Pakistani youth
}

Miknel Rytтев Aarhus University

\begin{abstract}
International literature shows that second-generation Pakistanis in the United Kingdom to a large extent marry spouses from the extended family in Pakistan. A similar picture was also recently to be found in Denmark. However, strict Danish legislation on family reunification introduced in 2002 and an increasing number of local love marriages have changed the overall picture. This article discusses how the new marriage preferences affect common notions of family relatedness, and suggests that young couples' decision to engage in a love marriage constitutes an act of symbolic mobility. Ultimately, Danish Pakistanis are split between the marriage preferences set up by their families, the Danish nation-state, and themselves. In this respect, marriage not only is about entering adulthood and deciding one's future, but also constitutes a process where notions of identity and belonging are negotiated within local and transnational families.
\end{abstract}

At first, Yasmeen and Imran, fellow Roskilde University students and occasional classmates, did not really notice each other and spoke only sporadically. Gradually, however, they became more and more interested in each other. They started communicating by e-mail, talked after class, and on one occasion they even risked getting caught and went to the movies together. Yasmeen and Imran were both well aware that by doing so, they were going well beyond the rules of purdah, the common code of acceptable behaviour for young unmarried men and women enforced by their families and the gossiping Pakistani migrant community in greater Copenhagen. Despite the interests of their respective parents, who wanted them to engage in arranged marriages with spouses from the extended family in Pakistan, they nevertheless decided to take their relationship to the next level and enter into a controversial love marriage. ${ }^{1}$ This article discusses the current trend of love marriages among Danish Pakistani youth: couples like Yasmeen and Imran reject the transnational marriages arranged by their parents and extended family and engage in local marriages based on romantic feelings. This article discusses how love marriages are embedded in discourses of identity, mobility, and modernity and how the popularity of local marriages affects notions of relatedness in transnational family networks.

Studies show that British-born children and even grandchildren of Pakistani immigrants are increasingly marrying spouses from Pakistan rather than partners born and raised in Britain (Shaw 2001: 316). One common explanation for this tendency is that 
transnational marriages are a means to create and strengthen the bonds of affiliation, continue labour migration, and maintain values and identity within the close family and extended kinship networks of biraderi (e.g. Ballard 1990; Charsley 2005; 2006; 2007; Shaw 2000; Werbner 1990). Recent studies have also emphasized the importance of more emotional aspects of kinship in order to explain the preference for transnational marriages within the extended family (Shaw \& Charsley 2006). Until recently a similar preference for transnational endogamous marriages was also to be found among the approximately 25,000 people with a Pakistani background who have been settled in Denmark since the late 1960 or 1970 s. $^{2}$ In 1989 , a national survey showed that more than 80 per cent of all marriages within the group of Danish Pakistanis aged 18-25 were contracted with spouses from Pakistan. However, in 2004, a new survey showed that in the group of Danish Pakistanis aged 17-27, more than 40 per cent were now engaged or married to spouses found in Denmark (Schmidt \& Jakobsen 2004: 111). The figures are probably even higher today, as the study concludes that there is a general tendency for an increasing number of immigrants to marry spouses from Denmark (Schmidt \& Jakobsen 2004: 112).

One obvious explanation for these figures could be that the immigration regime of Denmark and the strict rules on family reunification introduced in 2002 have had a strong impact on migrant families and have successfully created new marriage patterns. As discussed elsewhere, hundreds of Danish Pakistanis have settled in Sweden in recent years in order to achieve family reunification with spouses from the extended family in Pakistan (see Rytter 2007; 2010; 2012; Schmidt 2011). However, a closer look at the expanding group of Danish Pakistanis who marry local spouses reveals that the new emerging marriage pattern is also a product of intergenerational dynamics, social mobility, and an ideal of marrying for love. Like Yasmeen and Imran, many Danish Pakistanis engage in love marriages, an emic term implying that young people find and select their spouses themselves and that this once-in-a-lifetime decision should be based on mutual romantic feelings. In this respect, the kind of love marriage that Danish Pakistani youth talk about, dream of, and strive for is a companionate marriage where emotional closeness is understood as both the foundation for and the goal of the marriage - an ideal which worldwide seems to have become a key trope as a claim for modern identity (Cole \& Thomas 2009; Collier 1997; Constable 2004; Hirsch \& Wardlow 2006).

After elaborating on how internal social mobility and intergenerational dynamics are combining with external legal interventions to stimulate the emergence of a new marriage pattern, the first part of this article discusses how Danish Pakistani youth are split between the diametrically opposite marriage preferences put forward by their parents and extended family and by the nation-state, which has determined marriage preferences for all Danish citizens by means of a complex of policies and legislation on family reunification (Rytter 2010). In order to grasp and analyse the critical period in which different aspirations for and ideas about the future meet and individual lifetrajectories have to be decided, I apply Jennifer Johnson-Hanks's notion of 'vital conjunctures' (2006: 22-3). Within this context, Danish Pakistanis' choice of a marriage partner on the basis of love and personal interests constitutes not only a public statement of 'who they are', but also a projection of 'who they want to be'. Love marriages are distinct from the traditional endogamous marriages, which young people often associate with their parents' 'village mentality', and are instead embedded in notions of individuality and modern lifestyles. In this respect, one might say that 'love has become something of a metaphor for social mobility' (Hunter 2009: 147). The irrevocable 
decision to marry against the preferences and interests of their parents and transnational families becomes an act of 'symbolic mobility' in which Danish Pakistani youth set a course towards a future in Denmark for themselves and their families.

The second part of the article presents the extended case of Yasmeen and Imran in order to discuss some of the dilemmas and conflicts commonly found in migrant families, when young couples suddenly decide to rebel against their parents' will and engage in romantic relationships and love marriages. The case illustrates how marriage becomes a means to negotiate, create, or re-create notions of relatedness, identity, and belonging within and between migrant families settled in Denmark and their wider transnational kinship networks.

The final part of the article discuss how the current trend of local love marriages, along with the limited possibilities for achieving family reunification with spouses from Pakistan, has pushed migrant families in the direction of new marriage-scapes: the numerous possibilities makes it possible to craft new identities and future horizons, but the contingency of the unknown also creates numerous challenges and headaches.

The article is based on data from different research projects carried out over the last ten years. The fieldwork for my Master's thesis from 2001 to 2002 included twenty-six semi-structured interviews with young Danish Pakistani men about their aspirations and experiences of arranged marriages. A study conducted at the Academy of Migration Studies in Denmark (AMID) from 2005 to 2006 included eighteen semi-structured interviews about marriage with transnational couples settled in Sweden, where one spouse is Danish Pakistani and the other is Pakistani. Finally, the article includes data collected during doctoral fieldwork from 2006 to 2008 focused on the intergenerational and transnational dynamics of Pakistani migrant families. As this article will make clear, marriage is a very sensitive topic in a small migrant community, and therefore all names and identifiable facts such as the number of siblings, place of residence, and education have been changed in order to protect the anonymity and integrity of my informants.

\section{Intergenerational dynamics and legal intervention}

The current trend of love marriages is part of a more general transformation of intimacy within Pakistani migrant families, where the relations, emotions, and obligations which constitute family and kinship networks are being renegotiated. In order to address these changes, I make an analytical distinction between internal intergenerational dynamics and external legal intervention by the Danish nation-state.

\section{Internal dynamics}

New marriage preferences are being negotiated between an ageing first generation and a rising second generation who have been quite successful in the free Danish educational system; whereas the parent's generation generally had no or little education before leaving Pakistan, the upcoming generation have the same level of educational achievement as the national average for young Danes (cf. Mikkelsen, Fenger-Grøndahl \& Shakoor 2010; Moldenhawer 2005). The institution of arranged marriage rests on the understanding that the younger generation should comply with the wishes and decisions of their family elders. However, Danish Pakistani youth do not necessarily share their parents' interest in a transnational marriage within the biraderi, but often want a partner with the same background as their own: in other words, a spouse with an education who has been brought up in Denmark or another Western country. The differences in upbringings, levels of education, job opportunities, and worldviews often create tensions and conflicts 
within migrant families which should not be underestimated. Danish Pakistani youth have managed to convert their parents' hard work and sacrifices into upward social mobility by becoming IT specialists, engineers, dentists, medical doctors, and so on (Rytter 2011). In the process, they have also gained financial independence; in fact, they may become the main providers for their families. The growing gap within Pakistani migrant families often becomes salient when it comes to marriage.

Still, love marriages are controversial within the Pakistani migrant community. Young people often try to keep their romance secret until they finally decide to get married and have their parents formally arrange the marriage for them, so that it can be presented to the wider migrant community and relatives in Pakistan as a traditional arranged marriage. Local love marriages, which obviously involve the refusal of potential spouses from the extended family in Pakistan, may result in broken transnational relationships and kinship networks.

\section{External intervention}

The decrease in transnational marriages is also an observable effect of the new strict legislation on family reunification introduced by the Danish government in 2002. Marriage migration has in many respects become the last legal route of entry into 'Fortress Europe', and many European countries have adjusted their rules on family reunification in order to protect their national interests against the uncontrolled inflow of foreign spouses (Beck-Gernsheim 2007; Kofman 2004). Owing to the introduction of five requirements regarding a minimum age of 24 , accommodation, personal finances, collateral, and 'national attachment' (see Rytter 2010), it has become difficult - not only for foreigners, but for Danish citizens as well, in particular those with immigrant backgrounds - to achieve family reunification with non-European spouses. Whereas a total number of 6,399 foreign spouses came to Denmark through family reunification in 2000, in 2009, the number was reduced to 3,662. Whereas 261 spouses came from Pakistan in 2000, the number was reduced to 132 in 2009. ${ }^{3}$

On the one hand, when the new immigration regime was introduced, it was presented within a discourse of humanism as a necessary means to save young, secondgeneration immigrants from being forced into transnational marriages by their parents and families. On the other hand, the new legislation was part of the general securitization and mobilization of national sentiments and values which took place in the wake of 11 September 2001, and as such was presented within a discourse of nationalism as an effective means of protecting national borders and interests (Hervik \& Rytter 2004). Since 2002, thousands of Danish citizens have moved to Sweden in order to achieve family reunification with foreign spouses as citizens of the European Union. As noted above, hundreds of Danish Pakistanis have also chosen this option. In this respect, the Danish legal measures can be said to break up families. However, at the same time, many have continued to commute on a daily basis between their legal residence in Sweden and their workplace, educational institution, friends, and family in Denmark (see Rytter 2007; 2012).

These internal and external processes are part of an overall transformation of the institution of marriage among Pakistanis in Denmark: the previous preference for transnational endogamous marriages is being replaced by a preference for spouses found in other parts of the world who are selected on the basis of a new set of criteria and as a result of processes in which the young couple have a greater say in the matter than in traditional arranged marriages. However, the current trend of love marriages 
among Danish Pakistani youth also rearranges intergenerational relations and connections between the families of the migrant community and can have severe implications for transnational family and kinship relations.

\section{Diametrically opposed preferences}

Children represent the future, which makes it crucial for significant others to direct or even control their life-choices and trajectories in order to reproduce the existing order. Marriage not only concerns the intergenerational transmission of property and values; it also concerns class positions, knowledge, and skills, as well as significant notions of identity and belonging within the family. Likewise, modern welfare states have significant interests in governing partner choice and the family formation of their citizens. This regulation is exercised through national policies and bureaucracy in combination with the educational system and the labour market (Sørhaug 1996: 130-1). In the following discussion, I explore how both the family and the Danish nation-state have significant interests in attempting to control and regulate the partner choice and life-trajectories of Danish Pakistani youth.

\section{The marriage preferences of the family}

In Pakistan and among the Pakistani diaspora, the institution of arranged marriage ideally implies that parents and adult children reach a joint decision concerning the future husband or wife. ${ }^{4}$ Marriage is not only the union of two individuals; it is also a relation between two families, and there are therefore inevitably different perspectives and interests at play in most marriage arrangements. The socio-cultural and religiously justified norms of gender segregation or purdah mean that unmarried Danish Pakistani women and men have limited opportunities to meet and get to know each other before the actual marriage. It is, furthermore, considered a sign of respect and a proof of a decent upbringing for young people to allow their parents to take an active part in the decision about where (in what family, in what country) the marriage is to take place. Conversely, it is also a parental duty and obligation to find eligible partners for their offspring. To arrange the marriages of one's children completes parenthood. But young people also need their parents' collaboration and approval so that they can formally give their rishta: that is, suggest a marriage connection between two families. A formal proposal is seldom made by young people themselves.

Pakistanis traditionally express a preference for marriages within the extended family, and the ideal match is often considered to be between first cousins (Ballard 1990; Shaw 2000; 2001; Werbner 1990). Such marriages are believed to confirm and strengthen already existing ties and notions of relatedness within the family. Another important argument in favour of this kind of marriage is that cousins can be assumed to know each other in advance. However, close relations between two cousins can also cause problems: for example, if they have known each other since early childhood and relate to each other as classificatory siblings rather than as potential partners in marriage (Charsley 2007: 1125). Marriage between first cousins is also believed to ease the bride's transition in the virilocal system from being her parents' daughter to becoming her husband's wife and the daughter-in-law in the house of his parents. In a consanguineous marriage, the bride's mother-in-law is already her aunt, which is believed to imply that she will not be as critical or demanding as she might be with a girl from an unknown family (Charsley 2005: 89). But again, this is a generalization. In real life, there may be numerous pragmatic reasons for not arranging marriages between children 
within the immediate family, and for seeking partners among more distant relatives, friends, neighbours, or business partners instead. Last but not least, marriage within the family can be a strategy to protect second-generation Pakistanis from being exploited in 'bogus marriages' (Charsley 2006: 1170) or becoming 'visa brides': that is, solely a means for a man to enter Europe (Wikan 2002: 262).

A study of marriage preferences and practices among Danish Pakistani men and their parents shows that the latter often prefer to recruit spouses from the extended family in Pakistan (Rytter 2003). This marriage preference reflects the assumption that marriages between equals and families that are 'alike' provide the best basis for a long-lasting marriage and family relationship in the years to come. ${ }^{5}$ However, any notion of equality naturally depends on defining criteria: the equality between families can be measured in relation to such parameters as educational level, occupation, economic resources, political orientation, religiosity, place of origin in Pakistan, or the family's zaat (clan) background.

When parents start looking for a daughter-in-law in Denmark for one reason or the other, they consider it important to find a girl from a Pakistani family they are already acquainted with and respect, typically a family from their native village, or at least from the same zaat. The absolute minimum criterion for Pakistani parents is that their daughter-in-law should be a Muslim, while the worst-case scenario is an ethnic Danish non-Muslim daughter-in-law (Rytter 2003: 58ff.). In this way, the parents and the extended family distinguish between potential partners and rank them them along a continuum of good and bad choices and several gradations in between (see Fig. 1).

Choosing a daughter-in-law from the extended family network is a way to confirm and renew connections and bonds with significant people and places that the immigrant family left behind decades ago. The widespread reluctance, at least in the beginning, of the first generation to marry in Denmark has to do with the risk and uncertainty of marrying into 'strange' and unknown families (Charsley 2007: 1120). The same is the case when it comes to marrying Muslim girls in Denmark with parents from other countries than Pakistan. Despite a common religious background and the general acknowledgement that Muslims are 'brothers' and 'sisters' of the ummah, there is often deep scepticism regarding whether differences in national background, language, and traditions can be overcome in everyday life in the domestic sphere. Ethnic Danish non-Muslim girls are often rejected as serious potential spouse material by both young men and their parents: one may have intimate relations and even sexual affairs with them, but when it comes to marriage, ethnic Danish women are not an option. They are often described as being too independent for Pakistani family life, too promiscuous, and marriages to them are all too likely to end in divorce.

\section{The marriage preferences of the nation-state}

From a historical perspective, the strict immigration legislation and policy on family reunification introduced in 2002 is the culmination of a growing public and political interest in the marriage of different immigrant groups which emerged in the 1990 in Denmark (e.g. Madsen 2002; Rytter 2003, 2006; Sareen 2003; Schmidt \& Jakobsen 2004; Schmidt, Liversage, Graversen, Jensen \& Jakobsen 2009) and in the rest of Scandinavia (e.g. Berg 1994; Bredal 1999; 2006; Schlytter 2004; Wikan 2002). This interest has been motivated by a number of cases in which young people (mostly women) with a background as immigrants and Muslims have stood forth in the media or in 
Marriage preferences of the family

\begin{tabular}{|l|l|l|l|l|}
\hline $\begin{array}{l}\text { 1. The close } \\
\text { family in }\end{array}$ & $\begin{array}{l}\text { 2. The extended } \\
\text { family } \\
\text { Pakistan } \\
\text { (consanguineous } \\
\text { (biraderi) in }\end{array}$ & $\begin{array}{l}\text { 3. Other } \\
\text { Pakistani } \\
\text { fakistan }\end{array}$ & $\begin{array}{l}\text { 4. Other Muslim } \\
\text { Denmark }\end{array}$ & $\begin{array}{l}\text { 5. Ethnic Danes } \\
\text { immigrants in } \\
\text { (non-Muslim) }\end{array}$ \\
\hline
\end{tabular}

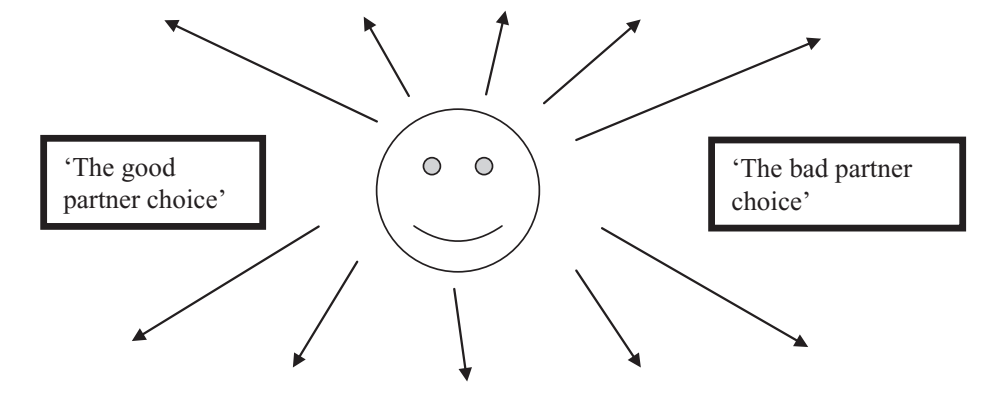

\begin{tabular}{|l|l|l|l|l|}
\hline $\begin{array}{l}\text { 1. Ethnic Danes } \\
\text { (non-Muslim) }\end{array}$ & $\begin{array}{l}\text { 2. Other Muslim } \\
\text { immigrants in } \\
\text { Denmark }\end{array}$ & $\begin{array}{l}\text { 3. Other } \\
\text { Pakistani } \\
\text { families in } \\
\text { Denmark }\end{array}$ & $\begin{array}{l}\text { 4. The extended } \\
\text { family } \\
\text { (biraderi) in } \\
\text { Pakistan }\end{array}$ & $\begin{array}{l}\text { 5. The close } \\
\text { family in } \\
\text { Pakistan } \\
\text { (consanguineous } \\
\text { marriage) }\end{array}$ \\
\hline
\end{tabular}

Marriage preferences of the nation-state

Figure 1. The diametrically opposed marriage preferences of Pakistani parents and the Danish nation-state. (The not-so-happy Smiley represents the position of Danish Pakistani youth.)

autobiographies and have recounted how they were forced into marriage by their families (Abdel 2000; Deveci 2004; Khader 1996; Kickbusch 2001; Osmani 2000; Rashid 2000; Svane 2002). These horrible cases have stimulated the creation of a sense of moral panic and have motivated politicians to take action in order to find a responsible solution to the apparently massive problems within the Muslim community. One goal has been to help young immigrants 'gain time', so that they can avoid being married at too young an age. ${ }^{6}$ It is a general assumption that an education postpones the final decision to marry until young people reach their mid-twenties, and that this delay empowers them to take a stand against the wishes and possible pressures of their parents, their family, and the Pakistani community in general (Government's Action Plan 2003). The current strict legislation on family reunification is a political signal that transnational marriages are not wanted in Denmark. Instead, second-generation immigrants are urged to find their partners inside the country. In this respect, the national legislation points out which partners the Danish nation-state considers 'good partner choices', while at the same time indicating clear preferences as to what constitute 'bad partner choices'. Choosing spouses from the extended transnational family is often presented in public discourse as an 'un-Danish' (udansk) practice that contrasts with the marriage preferences of 'real' Danes (Rytter 2010; Schmidt 2011). Transnational marriages are also seen as an indicator of a failed integration process, which in this context has connotations of a morbid and unhealthy state of existence. Another aspect is the heightened risk of producing disabled children in consanguineous marriages (cf. 
Shaw 2001), which is twice as great as in other kinds of marriages, according to the Danish government (Government's Action Plan 2003: 4). This warning indicates that, from the official point of view, the only morally responsible course of action is to abolish the preference for transnational marriages within the family network. Even though marriages between cousins are legal under Danish legislation on marriage, cousin marriages within the immigrant population are presented as morally suspect and as resulting in genetic degeneration.

In short, the Danish nation-state has set up an alternative marriage preference for the Muslim immigrant population. In contrast to the preferences of the parents, the nationstate urges second-generation immigrants to marry within Denmark and preferably to enter into an inter-ethnic and inter-religious relationship with a Danish spouse. Above all, Danish Pakistanis are encouraged to defy the tradition of transnational marriages and especially not to marry within the extended family network, as both of these types of connections are presented as irresponsible and morally reprehensible.

As illustrated in Figure 1, the marriage preferences of the family and the Danish nation-state are diametrically opposed. In the first scenario, the family offers all the privileges, rights, and obligations associated with the transnational kinship network, as well as the possibility of renewing practical and emotional connections and bonds with relatives and significant places and spaces in Pakistan. In the second scenario, the nation-state offers a future of being fully recognized and accepted as a Danish citizen, which also includes access to the privileges of the welfare system.

\section{The vital conjuncture of partner choices}

The choice of marriage partner constitutes a critical period in the life of young Danish Pakistanis where different aspirations and ideas meet. No matter what decision they finally end up taking, it will have consequences not only for themselves, but also for numerous people in their local and transnational families. It is these kinds of intense life situations that Jennifer Johnson-Hanks (2002; 2006) suggests we call 'vital conjunctures'. She introduces the concept to address periods of potential transformation (such as death, divorce, pregnancy, or childbirth) where the direction of individual lifetrajectories changes (Johnson-Hanks 2006: 22-3), and suggests that structural transitions are much more open and contested temporal periods of uncertainty, innovation, and ambivalence than acknowledged by traditional ethnographic categories (2002: 865). The concept of vital conjunctures can therefore be used to grasp and analyse the vital events of human life which cause previously steady trajectories to shift direction and which lead to the formation of new horizons.

The current immigration policy and legislation on family reunification has created a vital conjuncture for young Danish Pakistanis. ${ }^{7}$ Any decision they make will inevitably include the rejection of others. But neither the family nor the nation-state accepts the rejection of their particular preference without sanctions. If second-generation Pakistanis refuse to adopt the preference of the nation-state, they have to leave the country in order to achieve family reunification with their new spouses (cf. Rytter 2007; 2010; 2012; Schmidt 2011). If, conversely, the family's preference is rejected, the parents - and maybe especially the transnational family - will interpret this as a neglect of the emotional and social bonds within the family and the norm of marriages within the biraderi. When migrants do not fulfil their obligations, this is often interpreted as an unmistakable sign that they feel that they have become too 'good' for their families and relatives in Pakistan and no longer want to invest in intimate family relationships. This 
neglect can end up creating family conflicts and ultimately lead to the reorganization of the transnational network. For this reason, Pakistani parents in Denmark sometimes react very strongly when their offspring do not comply with their wishes or even reject an already planned rishta within the transnational family network. Young Danish Pakistanis who insist on marrying a husband or wife against the will of their parents (and transnational family) risk the sanction of longer or shorter periods of 'social death', where they are ignored and not considered part of the family (Charsley 2007: 1122). On rare occasions, young people who do not comply with the plans of the family have been punished by actual death, becoming the victims of so-called 'honour killings' (Møller 2007; see also Wikan 2003).

In the following section, I will present the extended case of how the love marriage of Yasmeen and Imran was brought about. I investigate the micro-politics of family life in order to illustrate what kinds of dilemmas and conflicts may be created within and between migrant families when Danish Pakistani youth no longer want to comply with the tradition of formal transnational arranged marriages, but instead outline alternative futures for themselves and their families.

\section{Imran and Yasmeen}

Imran is 27 and a student at Roskilde University. He is the oldest of four siblings and has always lived with his parents in a suburb south of Copenhagen. His father and mother both originate from smaller villages in the Gujrat district, like the majority of Pakistani migrants in Denmark (Quraishy 1999). Imran has a relatively large family in Denmark, since one of his paternal uncles and a paternal aunt live here with their spouses and children. Imran's grandmother also lives in Denmark.

Yasmeen is 26 and also a student at the university. Her father died years ago, so she lives alone with her mother and three siblings. Her mother comes from the city of Faisalabad in the heart of Punjab, a major city compared to the villages from which Imran's family originate. Yasmeen is the second oldest of the children in her family. Her older brother is engaged to a young woman from the family network in Pakistan. The plan is that in time they will marry and she will then come to Denmark through family reunification. Yasmeen has no other family in Denmark, but she has paternal aunts in Belgium, Holland, and France. All remaining family members on the mother's side live in Pakistan.

As mentioned at the beginning of this article, Yasmeen and Imran met each other at the university, and later initiated a romantic relationship. However, they both emphasized during our conversations that their relationship back then was purely platonic and that they did not transgress any religious boundaries regarding what is acceptable behaviour for unmarried women and men. When I asked whether they had made their decision to marry on the basis of love, Imran explained:

\footnotetext{
Yes ... and no. We were in love. But at the same time ... it was also because we matched each other on many fronts and shared many interests. We had the same ideas about our family and married life. So it was also to some extent a pragmatic decision. We had been looking at each other for a long time. We did not just rush into it.
}

When Yasmeen and Imran learned that they shared common interests and dreams for the future, they decided to take their relationship to the next level: they decided to get married. 


\section{Imran's troubles}

In order to be married, in the first place Yasmeen and Imran needed their families' acceptance (and ideally their blessing), and in the second place they needed to get their parents to arrange the rishta formally between the two families. 'To do it right' the boy's parents officially ask the girl's parents for the hand of their daughter, so Imran had to confront his parents and tell them that he had met a girl whom he wanted to marry. He was very nervous about the outcome of this confrontation, for three specific reasons.

First of all, Imran knew for a fact that his parents preferred that he marry within the extended family in Pakistan. A year before his relationship with Yasmeen started becoming serious, he had been in Pakistan with his father and younger brother, and here his father had explained that at his age (then 25) it was time to start thinking about marriage, and now that they were already in Pakistan it would be obvious for them 'to look around' (se os omkring). However, at this time, the idea of a future with Yasmeen had already begun to take shape in Imran's mind, so he refrained from making any decision in that regard, though without making it clear to his father that he might not be interested in a wife from Pakistan at all, but preferred a partner from Denmark instead.

Secondly, a marriage connection between Yasmeen and Imran was complicated by the fact that the families did not have any prior relationship with each other and, even worse, had different backgrounds. Not only did Imran's family come from a village whereas Yasmeen's came from a large city, the two families also had different zaat backgrounds. Imran's family were Jat and Chaudry, an overall category for families with land. There are many families in Denmark who call themselves Chaudry. However, Yasmeen's family were of the lineage of Rajputs, who converted from Hinduism to Islam generations ago. According to Imran, both zaat rank high in the overall hierarchy, which in the end made the rishta acceptable to his parents. As Imran's father confided to him on a later occasion: 'Yes, after all it was good that it was not a family from a lower ranking zaat that you were married to'.

But there was a third and more fundamental obstacle to their future wedding plans: Yasmeen was already engaged to a man in Pakistan. Owing to this delicate situation, in which Imran wanted to marry a woman outside the biraderi, from another zaat, and a different part of Pakistan, and who furthermore was already engaged, it took him almost three weeks to find the courage to confront his parents and tell them about Yasmeen. But by then he had no other choice, because gossip about their relationship had started to circulate in the migrant community. About this nerve-wracking period, Imran explained:

\footnotetext{
I had told my friends that I knew a Pakistani girl, but it was a long process where we started to develop these feelings for each other. In the beginning we did not think so much about it, but when the gossip started I got really nervous. I was not concerned for myself or about what people may think of me. But there is this with my mum and dad, they are part of this Pakistani spider's web where rumours about me would give them a hard time - and so they eventually did. It was not Imran, but Chaudry's son who had started having lady friends.
}

When he finally told them, his parents were very upset and disappointed that their son wanted a partner from Denmark despite their explicit preference for a daughter-in-law from Pakistan, and that he had been pursuing a secret relationship with Yasmeen and had thereby jeopardized the honour and respect of the entire family. But because Imran's romance was about to turn into a 'public secret', they had no other option but to try to arrange the marriage. 


\section{Yasmeen's other engagement}

When Yasmeen met Imran, she was already engaged to her maternal aunt's son. They had become engaged when she had gone on a summer holiday in Pakistan with her mother at the age of 19. Back then, her mother had actively tried to influence her decision by constantly talking positively about her cousin and complimenting him on his looks and letting her know how happy it would make her if Yasmeen were to marry him. Being a widow without any family in Denmark, Yasmeen's mother was uncertain about her future and old age, but by having her daughter engaged to her sister's son, she could re-establish a link to her family in Pakistan. This marriage would furthermore be economically advantageous to the family because the marriage would give the young man the opportunity to come to Denmark, earn money, and support the family back home. So in order to make her mother happy, Yasmeen agreed to the engagement.

Despite all these convenient reasons, Yasmeen felt a growing unease with her fiancé. For her, one potential future problem was that she herself was heading towards higher education, while her fiancé had no education at all. She asked him to acquire an education in Pakistan numerous times, so that he would be prepared to get a job when he came to Denmark later. But despite her requests nothing happened in this respect.

If Yasmeen and Imran were to be married, she would have to break off the engagement with her cousin. This would, however, put her mother in bad standing with her sister, and probably also with the rest of the family in Pakistan (see Fig. 2).

Previous episodes in the family history meant that a broken engagement would have serious consequences for Yasmeen's mother (1). (The numbers in this section refer to Fig. 2.) Years ago, Yasmeen's maternal aunt and her husband had arranged for the engagement of two of their sons to the uncle's sister's two daughters. After a while, both engagements were annulled, because the young women and their parents wanted to find

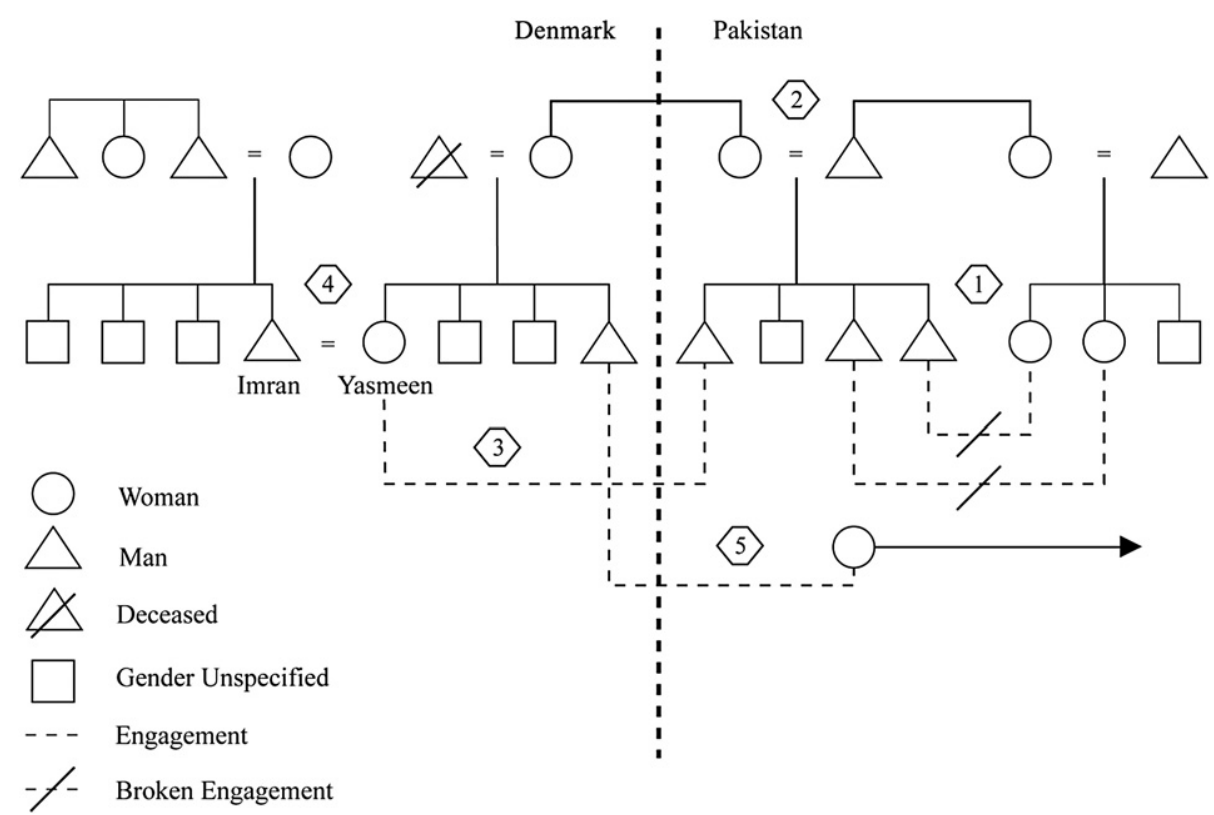

Figure 2. The complex family conflict in which Yasmeen and Imran were suddenly involved. 
more educated and eligible partners (2). Enraged that she and her sons had been rejected in such a humiliating way, Yasmeen's aunt demanded of her husband that he break off all contact with his sister, which he complied with in order to restore the family's public face and reputation (3). When Yasmeen, years later, became engaged to a third son, her cousin in Pakistan, she inadvertently became part of this family conflict (4), because if she were to break off the engagement with her fiancé and marry Imran instead, this family history would repeat itself. In that event, her uncle would be entitled to reciprocate the ultimatum he had been given, and demand that his wife break off all contact with her sister (Yasmeen's mother) in Denmark, a demand that would restore some of the prestige and dignity lost after having a son rejected after years of engagement.

By falling in love and deciding to get married, Yasmeen and Imran became the centre of a complicated family drama in which the worst possible scenario was that Yasmeen's mother would be cut off from her family and network in Pakistan. Yasmeen was aware of this, so she could not tell her mother directly about her relationship with Imran. Instead, she just told her that a boy from the university and his parents would like to come for a visit. Immediately her mother understood what was going on. First she was furious, and then she started crying. In a desperate attempt to make her daughter change her mind, she declared that Yasmen was no longer her daughter and informed the rest of her children that they were not allowed to talk or listen to their sister.

When Imran's father later visited Yasmeen's mother for the first time in order to meet Yasmeen and discuss the possibility of connecting the two families in marriage, the mother's concern about losing contact with her family in Pakistan was the major topic of conversation. At the time, Yasmeen's mother was also worried about her son (5). He had recently been married in Pakistan and was waiting for his wife to be granted family reunification to Denmark. He now risked being punished by the family in retaliation if Yasmeen broke off her engagement. ${ }^{8}$ Yasmeen's mother would therefore under no circumstances allow Yasmeen to be married before her new daughter-in-law had arrived in Denmark.

Yasmeen's mother had a hard time relating the bad news to the transnational family. In fact, she waited until after the wedding before calling her sister in Pakistan and informing her that the engagement had been called off because Yasmeen had married a man from Denmark of her own accord. When Yasmeen visits her mother today, she is no longer supposed to answer the phone, because Yasmeens's mother has officially cut her connection with her independent and disobedient daughter in relation to the extended family.

Fundamentally, neither Imran's nor Yasmeen's parents approved of the marriage in the beginning, but they all went along with the decision and the wishes of the young couple in the end. Parents walk a tightrope between suggesting eligible candidates and attempting to orientate the trajectories of their children in certain directions, all the while risking that the young people will go ahead and make decisions about their marital futures without the consent of the parents. Often parents and adult children meet somewhere in between. This was also the case for Imran and Yasmeen. Approximately one year after Imran first told his parents about Yasmeen, they were married at a discreet wedding with 'only' a hundred guests. Yasmeen explained why they did not have the traditional big wedding: 'It would have been like inviting people to come and see all the trouble'.

\section{Marriage and mobility}

Yasmeen and Imran ended up getting married despite all the problems they initially faced in their local and transnational families. But just because young people succeed in 
convincing their parents to go along with and arrange a love marriage, the couples do not necessarily 'live happily ever after'. After the wedding comes the time when the strength of the newlyweds' mutual feelings and aspirations are tested against members of the two families who might have preferred to see them married to someone else. Yasmeen's mother did not start speaking to her again until six months after the wedding, and even then never with the same level of intimacy as before. When I interviewed Yasmeen, her mother was still hurt and disappointed. When Imran visited, she gave him few openings to start building a relationship with her and fulfilling his practical and emotional duties and obligations as son-in-law. The only comfort was that Yasmeen's older brother had fully accepted Imran.

Right after the wedding, the couple moved into Imran's parents' apartment in order for them to get to know each other. In this respect they complied with the virilocal ideal, but after a while they realized that this housing situation gave them very little privacy to prioritize each other and their studies. Yasmeen explained:

\begin{abstract}
Imran would like to live at home, but I do not. His family is really nice. But I think that if we live too close it will increase the tensions. We lived there for a while after our wedding ... Imran's father does not really speak to him anymore because we moved out. They [the first generation] see it another way [than we do]. They may think that we are leaving because we do not like them. But I would like to have some privacy.
\end{abstract}

So after six months they moved into an apartment just five minutes away. Imran's father, however, was not satisfied with this arrangement. Once again he had to listen to the community gossip about his independent and unruly son and daughter-in-law. Once again his paternal authority and ability to raise his children were called into question.

The case of Yasmeen and Imran shows that migration is never a once-and-for-all move, but rather a continuous process in which historical background still influences and guides the interests, aspirations, and decisions that migrants make. It therefore seems useful to supplement our understanding of physical migration with a concept that can address the kind of 'symbolic mobility' that is part of any vital conjuncture people may face. Whereas physical mobility concerns the move from Pakistan to Denmark, symbolic mobility refers to the various social practices - that is, gestures, speech acts, gifts, or life-phase transitions such as marriage - through which migrants confirm, contest, or re-create their senses of relatedness and belonging to specific places or significant imagined communities (cf. Carsten 2000). Second-generation Pakistanis are often born and raised in Denmark, but they are nevertheless absorbed in social games at home, among Pakistani friends or in the migrant community, through which they relate to the country their parents left behind and to the ways in which everyday life was organized in that socio-cultural environment. While physical mobility is the irrevocable movement from A to B, symbolic mobility refers to the ways in which we constantly adjust our life-trajectories towards more or less distant horizons. Yasmeen and Imran's marriage can be interpreted as a kind of symbolic mobility: in choosing each other, the parental love which is ultimately confirmed by accepting an arranged marriage is redirected and transformed into romantic love for a member of another family. In this process, young Danish Pakistanis to some extent distance themselves from their parents and extended family and head towards a common future in Denmark. 


\section{Marriage patterns and notions of relatedness}

The case of Yasmeen and Imran highlights several general dilemmas which the trend of love marriages has created within and between migrant families. In this section, I discuss how these new marriage preferences affect the Pakistani migrant community and relations of transnational family networks in general.

Currently, first-generation Pakistani parents have started to view the marriage of their offspring as a means to social mobility whereby the middle-class status achieved in Denmark can be converted into favourable rishtas (Rytter 2011: 207). Many parents have learned from their married children that arranged marriages contracted with partners from the family network in Pakistan can be dysfunctional and may leave their children unhappy; but, provided first-generation migrants have already married their oldest son or daughter within the biraderi, they are partially relieved of family and kinship obligations, and can start to look in new directions in their search for spouses for their children. In this process, the strong ties consolidated by transnational marriages within the family are being replaced by the creation of weak ties by which Pakistani migrants reach out and connect to new networks of migrant families in Denmark or the rest of Europe, the Middle East, or North America, or even uppermiddle-class families in Pakistan's major cities such as Karachi, Lahore, or Islamabad (cf. Werbner 1999: 27-8). In this respect, the strict Danish immigration regime of 2002 has pushed families in the direction of new marriage-scapes (Constable 2004: 4) and made it acceptable to go beyond the transnational - but still narrow - family network, and to recruit spouses from new and wider circles.

Not everyone, however, ends up in a love marriage like Yasmeen and Imran. Members of both older and younger generations explain that it is actually difficult to find eligible matches in Denmark. First of all, there are relatively few Danish Pakistanis of the opposite sex in the same age group who are not already married or engaged. Furthermore, there is the problem of meeting candidates without jeopardizing your reputation or the honour of the family - here educational settings, associations, and the Internet seem to be favoured options. Another crucial aspect is the increasing importance of education in matching families that are alike. Once, on a taxi ride in Copenhagen, my Danish Pakistani driver related how his rishta had been refused three times by different families because he was 'only driving a taxi'. Owing to his lack of education, no Danish Pakistani woman and family would marry him. Instead his parents were now arranging a marriage for him in Pakistan. Turning this example around, it is also a growing problem that young women with an immigrant background are more successful than their male counterparts in the educational system (cf. Mikkelsen et al. 2010: 134). Getting an education is an accepted way to postpone the family's marriage plans, and many seem to use this as a deliberate strategy to get an education and start a career. Unfortunately, however, the increasing population of educated women with immigrant backgrounds (including Danish Pakistani women) lack men with similar backgrounds and educational qualifications to marry. One strategy in this situation is for the family to start looking for matches in other countries or for the young woman to fall in love with a man from another ethnic background.

The issues of the numbers and categories of eligible partners are not the only causes of problems; it can also be difficult to create and cultivate lasting relationships of mutual trust and affection between two families which have previously considered each other 'strangers' owing to differences in place of origin, zaat, religious orientation, and so on. It has been suggested that endogamous marriage within the extended family is a 
means by which Pakistani migrants can reduce the risk and avoid the uncertainty of marrying unknown families (Charsley 2006; 2007). Conversely, the problem can also be that two families know each other too well. Many male Pakistani migrants lived and worked together in 'the golden age' of the late 1960s and early 1970s before their wives and children arrived: back then many of the respectable elders of today had a more exploratory approach to life that might have included consumption of alcohol, illegal activities, sexual relations, or extramarital affairs with Danish women (Rytter 2011: 201-2). In this respect, both 'unknown' and 'all-too-well-known' families may have numerous skeletons in the closet that disqualify them as a reliable marriage potential.

Along with the strict Danish legislation on family reunification and the growing interest in local marriages, the institution of the matchmaker has gained prominence. When I interviewed Mrs Ghafoor, a middle-aged married woman and mother of three children, about her informal matchmaking service, she explained that Danish Pakistani men and their families often have unrealistic expectations about what rishta they can expect. Mrs Ghafoor had two booklets where shelisted her'customers', including their age, height, weight, family and zaat background, education and current job, interests, and approach to religion. One example she gave was of a man with a university degree who worked for a large Danish company and was from what Mrs Ghafoor referred to as 'a good family'. Still, she had no potential spouses for him; not only had he been married once before, he was also below average height and had started to lose his hair. The highly educated women listed in her other booklet would never be content with this rishta.

Finally, many young Danish Pakistanis stress their religious identities and use the choice of life-partner as a means to emphasize that, contrary to their parents, they consider themselves to be 'Muslim' before they are 'Pakistani', which often means that they find and marry spouses who are Muslim but from another immigrant group. Such religiously motivated marriages mark a distance from the gossiping Pakistani migrant community and the various cultural traditions considered un-Islamic, such as the parents' emphasis on zaat endogamy. However, the choice of a Muslim, non-Pakistani spouse often results in numerous challenges after the wedding, when the couple must learn to navigate between two different nationalities, languages, traditions, and family backgrounds.

All examples above are intended to illustrate how the emerging marriage-scapes and changing notions of relatedness and intimacy not only offer possibilities, but also create numerous new challenges for Danish Pakistani youth and their families in their quest for eligible partners.

\section{Conclusion: transformation and continuity}

Anthony Giddens has suggested that an integrated aspect of late modernity is the emergence of so-called 'pure relationships', where romantic feelings and relationships supposedly are separated from wider social or familial obligation (1992: 58). Even though Danish Pakistani love marriages might constitute such a radical break from the previous traditions of arranged marriages, many young couples still try to 'do it the right way', which implies that they attempt to make their evolving romantic liaisons and love marriages follow the 'script' of formally arranged marriages. Young couples like Yasmeen and Imran might follow their own aspirations and desires by entering more or less controversial love marriages, but they also relate to the values and traditions of rishta, zaat, virilocality, or biraderi, which continue to be important in the migrant community. The current trend of love marriages is obviously a symptom of an ongoing 'transformation of intimacy', as suggested by Giddens (1992). However, they do not 
indicate a fundamental rejection or break with previous marriage traditions in Pakistani families; rather they constitute a subtle redefinition of existing practices. The simultaneous processes of transformation and continuity in Pakistani marriage patterns and preferences exemplify how migrants may adopt to their new circumstances in European countries without assimilating to the whole package of individualistic values.

The extended case of Yasmeen and Imran also suggests that Danish Pakistani youth often find themselves in a vital conjuncture, caught between the preferences of their family and the nation-state. Much is at stake for migrants when it comes to marriage. Not only do relationships with parents in Denmark risk being seriously damaged when young people 'suddenly' want to choose their partners themselves, but the connections to significant people and places related to the Pakistani branch of the transnational family are also at stake. Just as marriage is the ultimate way to create or maintain transnational relations, it can also be an event that may cause conflict and reorganize the moral orders of emotions, duties, and obligations within transnational family networks. Thus, I have suggested that when young Danish Pakistanis choose to engage in a love marriage with a spouse from Denmark, the decision is often explained and justified within discourses on identity and modernity; in this respect a love marriage constitutes an act of 'symbolic mobility' whereby young people map out the direction of their future life-trajectories.

Despite their popularity, love marriages are still controversial within the relatively small migrant community. None the less, the scandalous character of these marriages will most likely disappear as more and more young couples meet, fall in love, and get married with (or without) the blessing of their parents and families. So even though the rejection of a rishta from the extended family may weaken or even break up connections to significant people and places in Pakistan, love marriages will become the foundation on which new intimate relations can be cultivated between migrant families in the diaspora. In this way, a love marriage between two families may be the first step in the creation of new biraderi-like relationships (Shaw 2000: 186).

Finally, this article has discussed why the marriage preferences and patterns of Danish Pakistani youth appear to differ from those of the Pakistani community in Britain. A future, more thorough, comparison should not only explore the impact of scale and migration history of the Pakistani communities but also pay more attention to how the socio-economic and political contexts of Britain and Denmark, respectively, have influenced marriage practices and family formation. Nevertheless, it has been suggested that the institution of marriage is changing due to the combination of intergenerational social mobility and legal interventions by the Danish nation-state in its attempts to regulate the pattern of transnational marriages. Paradoxically, the legal restrictions on family reunification which have drastically reduced the possibility of marriage migration of Pakistani spouses have at the same time provided Danish Pakistani youth with various new options beyond the endogamous circles of the extended family. None the less, it should be emphasized that current immigration policy also creates huge problems for the segment of Danish Pakistanis who actually want a spouse from Pakistan, and who therefore have to move to Sweden or another country of the European Union in order to achieve family reunification.

\section{NOTES}

The model of diametrically opposite marriage preferences (Fig. 1 in this article) was introduced in a Swedish anthology (Rytter 2007), while the extended case of Yasmeen and Imran first appeared in a Danish 


\section{MIKKEL RYTTER}

anthology (Rytter 2005). Different parts of this article benefited from comments and suggestions provided by Lisa Åkesson, Marita Eastmond, Laura Gilliam, Karen Fog Olwig, and Karen Valentin. I also thank Nadine Fernandez, Lenore Messick, and Bjarke Oxlund for help with language, literature, and love. Finally, I am grateful to the comments and suggestions by the three JRAI reviewers and the editor, Matthew Engelke, which helped improve earlier versions of this article.

${ }^{1}$ The notion of 'love marriage' is used in emic discourse among Danish Pakistani youth and implies that the young couple have met, fallen in love, and married with or without the consent of their respective parents. It is often emphasized that a love marriage does not necessarily imply any kind of physical relationship between the young couple prior to the wedding.

${ }^{2}$ The majority of the Pakistanis in Denmark come from villages in Gujrat and Jhelum district in rural Punjab. As the same can be said for Pakistanis in Norway, the area is sometimes referred to as 'Little Scandinavia. Many marriages are being arranged between branches of transnational families settled in Denmark and Norway. The rest of the Pakistani families in Denmark originate from larger cities such as Lahore, Karachi, Rawalpindi, or Sialkot.

${ }^{3}$ Total number of family reunifications to Denmark, 2000-9: 6,399 (2000), 6,499 (2001), 4,880 (2002), 2,538 (2003), 2,344 (2004), 2,498 (2005), 2,787 (2006), 3,616 (2007), 3,071 (2008), 3,662 (2009). Total number of spouses coming from Pakistan to Denmark, 2000-9: 261 (2000), 206 (2001), 190 (2002), 51 (2003), 40 (2004), 53 (2005), 54 (2006), 103 (2007), 88 (2008), 132 (2009). The effect of the current immigration regime introduced in 2002 is obvious. The statistics are extracted from the publication 'Tal og fakta på udlændingeområdet' $(2005,2009)$ found on http://www.NyiDanmark.dk.

${ }^{4}$ I am well aware that this definition neglects the aspect of power when it comes to selecting partners, and that some marriages are 'forced marriages', because they are arranged without the consent of the young people involved (cf. Samad \& Eade 1996).

${ }^{5}$ Norwegian anthropologist Thomas Walle (2004: 120) suggests that Pakistanis in Norway, like those in Denmark, express an explicit preference for isogamous marriages: that is, marriage alliances contracted between families who are structurally equal and alike. In a British context, other scholars have suggested the term homogamy, which refers to the selection of a partner from a similar social background shaped, for example, by race, class, ethnicity, religion, age, and education (Samad \& Eade 1996: 29).

${ }^{6}$ This is also the main political argument and justification for introducing the minimum age of 24 for both spouses (24-års regel) in order to be eligible for family reunification to Denmark.

${ }^{7}$ Marriage always constitutes a 'vital conjuncture' where different aspirations and interests regarding the couple's current and future lives are presented and discussed. However, since the introduction of the new national immigration policy, the Danish nation-state has interfered in this process and presented an alternative marriage preference for local spouses.

${ }^{8}$ Yasmeen's mother feared that the family in Pakistan would not let her daughter-in-law come to Denmark if Yasmeen broke off the engagement with her maternal cousin. Pnina Werbner (1999) presents a case where a divorce in the biraderi was reciprocated by numerous other divorces in the transnational network in order to even up the balance.

\section{REFERENCES}

Abdel, M. 2000. Mod min vilje. Aarhus: CDR Forlag.

BALLARD, R. 1990. Migration and kinship: the differential effect of marriage rules on the processes of Punjabi migration to Britain. In South Asians overseas (eds) C. Clarke, C. Peach \& S. Vertovec, 219-49. Cambridge: University Press.

Beck-Gernsheim, E. 2007. Transnational lives, transnational marriages: a review of the evidence from migrant communities in Europe. Global Networks 7, 271-88.

BERG, M. 1994. Seldas andra bröllup. Göteborg: Etnologiske föreningen i Västsverige.

Bredal, A. 1999. Arrangerte ekteskab og tvangsekteskab i Norden. Tema Nord, Nordisk Ministerråd. 2006. 'Vi er jo familie': arrangerte ekteskab, autonomi og fellesskab blant unge norsk-asiater. Ph.D. thesis, Institut for Samfunnsforskning, Unipax.

CARsten, J. 2000. Introduction: cultures of relatedness. In Cultures of relatedness: new approaches to the study of kinship (ed.) J. Carsten, 1-37. Cambridge: University Press.

Charsley, K. 2005. Unhappy husbands: masculinity and migration in transnational Pakistani marriages. Journal of the Royal Anthropological Institute (N.S.) 11, 85-105. 2006. Risk and ritual: the protection of British Pakistani women in transnational marriage. Journal of Ethnic and Migration Studies 32, 1169-87. 
2007. Risk, trust, gender and transnational cousin marriage among British Pakistanis. Ethnic and Racial Studies 30, 1117-31.

Cole, J. \& L. Thomas (eds) 2009. Love in Africa. Chicago: University Press.

Collier, J. 1997. From duty to desire: remaking families in a Spanish village. Princeton: University Press.

Constable, N. (eds) 2004. Cross-border marriages: gender and mobility in transnational Asia. Philadelphia: University of Pennsylvania Press.

Deveci, A. 2004. Tvang. Copenhagen: Aschehoug.

Giddens, A. 1992. The transformation of intimacy: sexuality, love and eroticism in modern societies. Cambridge: Polity.

Government's Action Plan for 2003-2005 On Forced, Quasi-forced and Arranged Marriages 2003. Danish government, 15 August (available on-line: http://www.nyidanmark.dk/NR/rdonlyres/o5ED38168159-4899-9CBB-CDD2D7BF23AE/o/forced_marriages.pdf, accessed 29 May 2012).

Hervik, P. \& M. Rytter 2004. Med ægteskab i fokus. In Egtefallesammenføring i Danmark (eds) B. Olsen, M.V. Liisberg \& M. Kjærum, 131-60. Udredning nr. 1. Institut for menneskerettigheder.

Hirsch, J. \& H. WARDlow (eds) 2006. Modern loves: the anthropology of romantic courtship and companionate marriage. Ann Arbor: University of Michigan Press.

Hunter, M. 2009. Providing love: sex and exchange in twentieth-century South Africa. In Love in Africa (eds) J. Cole \& L. Thomas, 135-55. Chicago: University Press.

Johnson-Hanks, J. 2002. On the limits of life stages in ethnography: toward a theory of vital conjunctures. American Anthropologist 104, 865-80.

2006. Uncertain honour: modern motherhood in an African crisis. Chicago: University Press.

Khader, N. 1996. Ere og Skam; det islamiske familie- og livsmønster fra undfangelse til grav. Valby: Borgen.

Kiсквusch, J. 2001. Karlighed med stort $M$ - Muslimske drenge og unge mond om karlighed, karester og aegteskab. Aarhus: CDR Forlag.

Kofman, E. 2004. Family-related migration: a critical review of European Studies. Journal of Ethnic and Migration Studies 30, 243-62.

Madsen, D. 2002. Kan tvang vare en aressag? Idekatalog til en dansk indsats mod tvangsagteskaber. Copenhagen: Videnscenter for ligestilling.

Mikkelsen, F., M. Fenger-Grøndahl \& T. Shakoor 2010. I Danmark er jeg født ... Etniske minoritetsunge i bevagelse. Copenhagen: Frydenlund.

Moldenhawer, B. 2005. Transnational migrant communities and education strategies among Pakistani youngsters in Denmark. Journal of Ethnic and Migration Studies 31, 51-78.

Møller, A.S. 2007. Ghazala - et aresdrab i Danmark. Aarhus: Siesta.

Osmani, N. 2000. Forbandede are. Aarhus: CDR Forlag.

QuRAishy, B. 1999. Fra Punjab til Vesterbro: det pakistanske samfund i Danmark. Copenhagen: Forlaget Etnisk Debatforum.

Rashid, R. 2000. Et løft af sløret. Copenhagen: Gyldendal, Nordisk Forlag A/S.

RytTER, M. 2003. Lige gift: en antropologisk undersøgelse af arrangerede ægteskaber blandt pakistanere i Danmark. Master Thesis no. 261, Department of Anthropology, University of Copenhagen.

- 2005. Ægteskab som bevægelse: positioner og interesser i et arrangeret ægteskab. In Lokale hverdagsliv, fjerne forbindelser: børn og unge i migrationsprocesser (eds) L. Gilliam, K.F. Olwig \& K. Valentin, 265-83. Copenhagen: Hans Reitzels Forlag.

2006. Ægteskabelig integration: pakistanske og danske arrangerede ægteskaber. In Den stille integration: nye fortallinger om at høre til i Danmark (eds) M.H. Pedersen \& M. Rytter, 18-43. Copenhagen: C.A. Reitzels Forlag.

2007. Giftermål över gränserne: arrangerade äktenskap bland dansk-pakistanier i Malmö. In Globala familjer: transnationel migration og släktskap (eds) M. Eastmond \& L. Åkesson, 175-204. Göteborg: Gidlunds.

2010. 'The family of Denmark' and 'the aliens': kinship images in Danish integration politics. Ethnos 75, 301-22.

2011. Money or education? Strategies of improvement among Pakistani families in Denmark. Journal of Ethnic and Migration Studies 37, 197-215.

2012. The semi-legal family life: Pakistani couples in the borderlands between Denmark and Sweden. Global Networks 12, 98-117.

SAMAD, Y. \& J. EADE 1996. Community perceptions of forced marriage. Report for the Community Liaison Unit (CLU). London: Foreign and Commonwealth Office. 
SAREEN, M. 2003. Når karlighed bliver tvang: generationskonflikter og tvangsagteskaber i Danmark. Copenhagen: People's Press.

SCHLytter, A. 2004. Rätten att själv få välja: arrangerade äktenskap, kön och socialt arbete. Lund: Studentlitteratur $\mathrm{AB}$.

SснміDт, G. 2011. Law and identity: transnational arranged marriages and the boundaries of Danishness. Journal of Ethnic and Migration Studies 37, 257-75.

\& V. JаковSEn 2004. Pardannelse blandt etniske minoriteter i Danmark. Copenhagen: Socialforsknings Instituttet.

- A. Liversage, B.K. Graversen, T.G. Jensen \& V. Jakobsen 2009. Endrede familiesammenføringsregler: hvad har de nye regler betydet for pardannelsesmønstret blandt etniske minoriteter? Copenhegen: SFI - Det nationale forskningscenter for velfærd 09:28.

Shaw, A. 2000. Kinship and continuity: Pakistani families in Britain. Amsterdam: Harwood Academic.

2001. Kinship, cultural preference and immigration: consanguineous marriage among British Pakistanis. Journal of the Royal Anthropological Institute (N.S.) 7, 315-34

\& K. Charsley 2006. Rishtas: adding emotions to strategy in understanding of British Pakistani transnational marriages. Global Networks 6, 405-21.

Sørнaug, T. 1996. Fornuftens fantasier: antropologiske essays om moderne livsformer. Oslo: Universitetsforlaget.

Svane, E. 2002. Sibel. Copenhagen: Ekstra Badets Forlag.

WALLE, T. 2004. Virginity vs decency: continuity and change in Pakistani men's perception of sexuality and women. In South Asian masculinities (eds) R. Chopra, C. Osella \& F. Osella, 96-130. Kali: New Delhi.

Werbner, P. 1990. The migration process: capital, gifts and offerings among British Pakistanis. New York: Berg. 1999. Global pathways: working-class cosmopolitans and the creation of transnational ethnic worlds Social Anthropology 7, 17-35.

WIKAN, U. 2002. Generous betrayal: politics of culture in the new Europe. Chicago: University Press. 2003. For arens skyld: are og drab, Fadime en sag til eftertanke. Copenhagen: Gyldendal.

\section{D'une préférence à l'autre: mariage et mobilité chez les jeunes Pakistanais du Danemark}

\section{Résumé}

De nombreuses publications internationales montrent que les Pakistanais de deuxième génération au Royaume-Uni se marient souvent au sein de leur famille élargie au Pakistan. Un constat semblable a aussi été dressé récemment pour le Danemark, mais la rigueur de la législation sur le regroupement familial votée en 2002 dans ce dernier pays et le nombre croissant de mariages d'amour locaux sont venus changer la donne. L'article décrit les conséquences des nouvelles préférences matrimoniales sur les conceptions habituelles de liens de parenté et suggère que la décision des jeunes couples de contracter un mariage d'amour constitue un acte de mobilité symbolique. En fin de compte, les jeunes Pakistanais du Danemark sont partagés entre les préférences matrimoniales établies par leur famille, l'État-nation danois et eux-mêmes. Le mariage n'est pas seulement un passage à l'âge adulte et une décision sur son propre avenir: il constitue aussi un processus au fil duquel les notions d'identité et d'appartenance se négocient au sein des familles locales aussi bien que transnationales.

Mikkel Rytter is Assistant Professor at the Department of Culture and Society, Aarhus University, where he participates in a cross-disciplinary research project on 'Sufism and Transnational Spirituality'.

Department of Culture and Society, Moesgaard allé 20, 8270 Hoejbjerg, Denmark. mikkel.rytter@hum.au.dk 